\title{
Differences in the development of the closely related myrmecophilous butterflies Maculinea alcon and M. rebeli (Lepidoptera: Lycaenidae)
}

\author{
MARCIN SIELEZNIEW ${ }^{1 *}$ and ANNA M. STANKIEWICZ ${ }^{2}$ \\ ${ }^{1}$ Department of Applied Entomology, SGGW - Warsaw Agriculture University, Nowoursynowska 159, PL-02-776 Warszawa, \\ Poland \\ ${ }^{2}$ Laboratory of Social and Myrmecophilous Insects, Museum and Institute of Zoology, Polish Academy of Sciences; Wilcza 64, \\ PL-00-679 Warszawa, Poland; e-mail: ams@miiz.waw.pl
}

Key words. Lycaenidae, Maculinea alcon, Maculinea rebeli, Myrmica ants, myrmecophily, host-ant specificity, growth rate, larval diapause, Gentiana pneumonanthe, Gentiana cruciata, endangered species, Poland

\begin{abstract}
The initially phytophagous caterpillars of Maculinea alcon and M. rebeli complete their development in Myrmica ant colonies as social parasites. Recent genetic studies show no differences at the species level among various populations of each butterfly taxa. Usually M. alcon and M. rebeli are identified by habitat and larval food plants (Gentianaceae) and host ant specificity is also considered to be an important feature. However most of the ecological characteristics overlap at least in some parts of their distributions. The developmental and survival characteristics of caterpillars reared by different Myrmica species were compared in laboratory experiments and in the field. Morphologically indistinguishable M. alcon and M. rebeli, which originated from Polish populations, are very similar in terms of host specificity i.e. larvae survived both with M. scabrinodis and M. sabuleti. However they showed different growth characteristics. The earlier flight period of M. rebeli, which is synchronized with the phenology of Gentiana cruciata, resulted from the quick growth of caterpillars in Myrmica nests in the pre-winter phase, when they gained about half of their final body biomass. After the end of winter they recommenced growth almost immediately. M. alcon larvae entered diapause shortly after adoption by ants and began to increase in weight significantly just one month after the onset of spring, which synchronized their development with that of their larval food plant, G. pneumonanthe. Therefore neither population group is transferable between habitats and should still be regarded, at least, as distinct conservational units.
\end{abstract}

\section{INTRODUCTION}

The obligatorily myrmecophilous butterflies, Maculinea alcon (Denis \& Schiffermüller, 1775) and M. rebeli Hirschke, 1904 are endangered in Europe (van Swaay \& Warren, 1999). Because of their complicated life-history and status representatives of the genus Maculinea van Eecke, 1915, are among the most intensively studied butterfly species in the world (Thomas \& Settele, 2004; Settele et al., 2005).

The separation of the species M. alcon and M. rebeli, always controversial (see Steiner et al., 2006 for a review), is strongly challenged by the results of the latest genetic (Als et al., 2004; Bereczki et al., 2005) and cladistic studies (Pech et al., 2004). Recently Steiner et al. (2006) did not find any differences in egg morphology and cuticular compounds of larvae from the type localities of M. alcon and M. rebeli in Austria.

For a long time, habitat and larval food plants rather than morphological characteristics, were used as the main criteria for attributing specimens to one species or the other. M. alcon was considered to be a hygrophil or mesophil using mainly Gentiana pneumonanthe and $M$. rebeli as a xerothermophil using mainly $G$. cruciata (Munguira \& Martin, 1999). However preferences for larval food plants are not clear-cut. M. alcon and $M$. rebeli oviposit on six and seven species of Gentiana or Gentianella, respectively (Jutzeler, 1988; Munguira \& Martin, 1999; Kolev, 2002; Stankiewicz et al., 2005b; Tartally \& Varga, 2005; Steiner et al., 2006). The most important conclusion of these observations is that $G$. pneumonanthe, the traditional larval food-plant of $M$. alcon, might also be used additionally by $M$. rebeli and vice versa. Females oviposit mostly on gentian buds and are probably guided by the physiological and chemical characteristics of a plant rather than preferences for a particular species (Sielezniew \& Stankiewicz, 2004a).

Besides larval foodplants, the presence of specific ants is another vital factor essential for the existence of both $M$. alcon and $M$. rebeli. During the first three stages, lasting 2-3 weeks, caterpillars are endophytic and eat developing flowers and seeds, but grow very little, gaining about $1.5 \%$ of their final biomass. Just after the fourth (final) moult they drop to the ground and await Myrmica ants. If a worker comes across a caterpillar within $48 \mathrm{~h}$ it is immediately taken to a nest in the same way as ant brood is carried. Retrieved caterpillars spend 10-22 months in colonies being fed by ants with regurgitations and insect prey, and they also eat host larvae. Caterpillars finally pupate in chambers close to the soil

\footnotetext{
* Corresponding and present address: Division of Invertebrate Zoology, Institute of Biology, University of Bialystok, Świerkowa 20B, PL-15-950 Białystok, Poland; e-mail: marcins@uwb.edu.pl
} 
surface and emerge as adults 3 weeks later (Elmes et al., 1991a, b).

This advanced myrmecophily is associated with chemical mimicry of ants (Akino et al., 1999). The adoption of the larvae and the first phase of their integration into an ant colony is triggered by the presence of a relatively simple set of hydrocarbon compounds in the cuticle. However, after some time caterpillars start to synthesize additional chemicals, which enable them to achieve a high social status in the nests of specific ants. If they are adopted by non-host ants the survival rate is poor and depends, among other factors, on the physiological state of the colony, e.g. food stress may increase mortality (Elmes et al., 2002, 2004; Schönrogge et al., 2004).

The first data on the host ants of Maculinea butterflies indicated a high level of specificity. M. alcon was found mainly in nests of $M$. ruginodis Nylander, 1846, while $M$. rebeli almost exclusively in $M$. schencki Emery, 1895 colonies (Thomas et al., 1989). Further studies revealed a much more complicated pattern of butterfly-ant relationships. First Elmes et al. (1994) discovered geographical variation in the host specificity of $M$. alcon, which used three different species along a north-south gradient: $M$. rubra (Linnaeus, 1758), M. ruginodis and M. scabrinodis Nylander, 1846. Next Als et al. (2002) revealed that in Denmark both $M$. rubra and $M$. ruginodis were parasitized at some sites. However in eastern parts of the European range $M$. alcon has never been recorded in colonies of these two species. M. scabrinodis is reported as a host of this butterfly in Poland (Sielezniew \& Stankiewicz, 2002) and Hungary (Tartally \& Varga, 2005) and additionally in some localities it develops successfully in nests of the closely related $M$. vandeli (Sielezniew \& Stankiewicz, 2004b) or M. salina (Tartally, 2005).

As far as $M$. rebeli is concerned $M$. schencki is not the major host in the east, except at the most northern, highly isolated sites in Lithuania (Stankiewicz et al., 2005c). In Austria and Hungary this butterfly is recorded associated with five species: M. sabuleti Meinert, 1846, M. scabrinodis, M. specioides Bondroit 1918, M. lonae Finzi, 1926 and M. schencki (Steiner et al., 2003; Tartally \& Varga, 2005). However in Poland M. schencki is not exploited, although it can be quite abundant and $M$. rebeli populations are supported by $M$. sabuleti and M. scabrinodis (Steiner et al., 2003; Stankiewicz \& Sielezniew, unpubl.). There is also an anecdotal observation of pupae in a $M$. rugulosa Nylander, 1846 nest at a site in the south-east of the country (Stankiewicz et al., 2005a).

One of the most important conclusions of field studies on the ant relationships of $M$. alcon and $M$. rebeli is overlapping host specificity in Eastern Europe. In Poland (Stankiewicz et al., 2005b) and Hungary (Tartally \& Varga, 2005) both species are found in colonies of $M$. scabrinodis, which is a widespread and quite tolerant ant encountered in various open and sunny grassland habitats except very dry ones (Elmes et al., 1998). Other Myrmica species, used by $M$. alcon or $M$. rebeli, usually have narrower niches and are more limited as potential hosts for both $M$. alcon and M. rebeli. For example M. sabuleti, the major host of $M$. rebeli, at many sites is confined to xerothermic meadows and absent from the typical wetter $M$. alcon habitats. Interestingly all the important hosts of "cuckoo" Maculinea in Eastern Europe are closely related and belong to the "scabrinodis" group. Therefore it is likely that the differences in host-ant specificity of $M$. alcon and $M$. rebeli in the region reflect only differences in ant species composition in their habitats.

To test this hypothesis and look for other possible characteristics, laboratory experiments were performed. The Polish populations of $M$. alcon and $M$. rebeli are particularly suitable for such studies because: (1) previous field data suggest that they are very similar to each other in terms of host ant specificity; (2) imagines do not differ morphologically but live in typical habitats i.e. wet or xerothermic meadows, respectively. The survival and growth of caterpillars were compared in artificial nests of a few Myrmica species, from both M. alcon and M. rebeli sites. The results of these studies combined with field observations are presented in this paper.

\section{MATERIAL AND METHODS}

\section{Collection of Maculinea}

Pre-adoption larvae of $M$. alcon were obtained from two populations. Most of the material was collected at "Jasiów" $\left(51^{\circ} 01^{\prime} \mathrm{N}, 20^{\circ} 39^{\prime} \mathrm{E} ; 350 \mathrm{~m}\right.$ a.s.l.) in the Świętokrzyskie region (southern Poland), where the butterfly develops in M. scabrinodis and $M$. vandeli nests. Details are given in Sielezniew \& Stankiewicz (2004b). The rest of the M. alcon stock originated from "Augustówka" near Warsaw $\left(51^{\circ} 59^{\prime} \mathrm{N}, 21^{\circ} 29^{\prime} \mathrm{E}, 100 \mathrm{~m}\right.$ a.s.1.), where $M$. scabrinodis is the host (Sielezniew \& Stankiewicz, 2002). However, all M. rebeli caterpillars originated from the biggest Polish population in Przemyśl $\left(49^{\circ} 46^{\prime} \mathrm{N}\right.$, $22^{\circ} 46^{\prime} \mathrm{E}, 320-350 \mathrm{~m}$ a.s.1) in south-eastern Poland, where both M. sabuleti and M. scabrinodis are hosts (Sielezniew et al., 2003).

Samples were collected in late July and early August 2003 and 2004. Twenty or thirty gentian shoots, with eggshells visible, which suggests the presence of caterpillars in flowerheads, were collected at each site. To avoid harming the populations plants were collected only from patches where caterpillars were unlikely to survive after dropping to the ground. Appropriate gentians were identified, i.e. those growing outside the foraging zone of host ants, by placing sugar baits close to them. If only non-host ants were attracted, shoots were considered for sampling. Cut shoots were immediately transported to the laboratory and put in plastic cups with water. The immersed parts of the stalks were wrapped with tissue to prevent caterpillars from drowning when leaving shoots. These bunches of shoots were kept in large plastic containers covered with a net to prevent caterpillars escaping.

Twice a day the gentians and containers were checked for the presence of just-emerged fourth instar caterpillars, which were then used for experiments, i.e., introduced into Myrmica ant colonies. The plants remained fresh for about two weeks, which enabled most of the caterpillars present to moult successfully to the fourth instar. Preliminary studies, like those of Elmes et al. (1991b), showed that small larvae had little chance of survival. Thus, only pre-adoption larvae with a weight of not less than 1 mg were used. A few small caterpillars, which left the shoots at an earlier instar were also rejected. 


\section{Collection of Myrmica}

All ant nests for the laboratory experiments originated from Maculinea sites or adjacent areas. In the butterfly habitats colonies situated in the vicinity of larval food plants were never chosen. In June and July 2003 and 2004, a total of 72 nests of seven Myrmica species were fully excavated with turf and quickly transported to the laboratory in big containers or bags. Colonies of M. scabrinodis, M. vandeli, M. gallienii, M. ruginodis and $M$. rubra were excavated on wet $M$. alcon meadows. From the dry $M$. rebeli habitat: $M$. sabuleti, $M$. schencki and $M$. scabrinodis colonies were obtained. Ants were identified according to Czechowski et al. (2002) and Radchenko et al. (2003). In the laboratory, nests were carefully dissected and all specimens were caught, counted and then put into artificial nests. If excavated colonies were very large, then they were divided into subcolonies of about 200-250 workers, one queen and a proportional number of brood. In this way a total of 145 laboratory colonies was formed (Table 1).

\section{Experimental design}

The techniques used to rear ants and caterpillars were similar to those described by Wardlaw (1991) and Wardlaw et al. (1998). Experimental colonies were maintained in covered plastic boxes, $24 \times 15 \times 5 \mathrm{~cm}$, with ventilation in the form of two openings $(1 \mathrm{~cm}$ in diameter) in the lid, each covered with fine netting. The upper parts of the sides of each box were coated with a thin layer of Fluon to prevent ants from escaping during manipulations that involved opening boxes. Two thin, moist rectangular sponges were placed in the bottom of each box. Two walnut shells, which served as shelters, were placed on the bigger sponge $(7 \times 5 \mathrm{~cm})$. The smaller sponge $(5 \times 3 \mathrm{~cm})$ at the opposite end was used as a watering place and kept a little wetter. Food was also provided every 2-3 days in the form of sugar and Drosophila flies (adults and larvae which originated from a permanent standard laboratory culture).

Boxes were cleaned once a week and walnut shells and sponges replaced if they became mouldy. Carbon dioxide was used to anaesthetise ants during major manipulations.

Originally five caterpillars of M. alcon or M. rebeli were to be introduced into every ant culture. However, because of variation in the availability of pre-adoption larvae and the necessity to complete the set within 1-2 days, the numbers occasionally differed slightly (3-6). M. alcon caterpillars were placed in the

TABLE 1 . Summary of the laboratory colonies of different species of ants that hosted Maculinea caterpillars.

\begin{tabular}{|c|c|c|c|c|}
\hline \multirow[t]{2}{*}{ Myrmica species } & \multirow{2}{*}{$\begin{array}{c}\text { No. of } \\
\text { nests } \\
\text { excavated }\end{array}$} & \multirow{2}{*}{$\begin{array}{l}\text { No. of } \\
\text { laboratory } \\
\text { colonies }\end{array}$} & \multicolumn{2}{|c|}{$\begin{array}{l}\text { No. of colonies } \\
\text { with introduced } \\
\text { caterpillars of }\end{array}$} \\
\hline & & & M. alcon & M. rebeli \\
\hline $\begin{array}{l}\text { M. scabrinodis } \\
\text { (from } M \text {. alcon sites) }\end{array}$ & 8 & 25 & 16 & 9 \\
\hline $\begin{array}{l}\text { M. scabrinodis } \\
\text { (from M. rebeli sites) }\end{array}$ & 7 & 34 & 20 & 14 \\
\hline M. scabrinodis (all) & 15 & 59 & 36 & 23 \\
\hline M. sabuleti & 15 & 22 & 12 & 10 \\
\hline M. vandeli & 4 & 6 & 6 & - \\
\hline M. gallienii & 6 & 25 & 25 & - \\
\hline M. rubra & 4 & 7 & 7 & - \\
\hline M. ruginodis & 4 & 12 & 12 & - \\
\hline M. schencki & 10 & 14 & 7 & 7 \\
\hline Total & 58 & 145 & 105 & 40 \\
\hline
\end{tabular}

nests of seven Myrmica species. Five of them were native to butterfly habitats in Poland (M. scabrinodis, M. vandeli, M. gallienii, M. ruginodis and $M$. rubra) and the remaining two originated from the $M$. rebeli site. As far as M. rebeli is concerned only three species (M. sabuleti, M. scabrinodis and M. schencki) were tested. There were insufficient number of caterpillars and further collecting could have affected the population. M. scabrinodis occurred at both the M. alcon and M. rebeli sites. As it is thought that there are two ecotypes of the species, i.e., xerophilous and hygrophilous ecotypes (Elmes et al., 1998) cross-over experiments were performed with both Maculinea species.

All caterpillars were weighed just before placing them in artificial nests and if they survived, measurements were continued regularly at $7( \pm 1)$ day intervals. Simultaneously, in most cases, length and diameter of caterpillars were measured to calculate the volume of each individual using the formula used by Als et al. (2002) for M. alcon, i.e. volume of cylinder with hemispherical ends:

$$
V=\pi r^{2}(l-2 r)+4 \pi r^{3} / 3
$$

where $r$ is the radius and $l$ is the total length. A regression between weight and volume was used to estimate the weight of larvae in the field, where direct measurements were impossible.

Boxes with ants and larvae were kept in a climatic chamber at a constant temperature of $20^{\circ} \mathrm{C}$ and a $14 \mathrm{~L}: 10 \mathrm{D}$ photoperiod. The main aim was to compare the survival and growth rates of $M$. alcon and $M$. rebeli over a period of eight weeks, i.e., the approximate duration of the pre-winter phase. After that most of the boxes were kept at a lower temperature $\left(6-10^{\circ} \mathrm{C}\right)$ and under short day conditions $(8 \mathrm{~L}: 16 \mathrm{D})$ for about 4 months (overwintering) and the others remained at $20^{\circ} \mathrm{C}$. Because of the high mortality of both ant workers and caterpillars during the winter period, due to disease rather than unsuitability of the host, it was not possible to continue observations. Very few individuals were reared to adulthood and therefore results from the postwinter phase were analyzed only in terms of growth rate.

\section{Field studies}

The growth of caterpillars in the field was studied at M. alcon sites in the Świętokrzyskie region and a M. rebeli site in Przemyśl. We looked for larvae and pupae in ant nests in late September/early October 2003, late April/early May, late May/early June and late June 2004. Areas within $1 \mathrm{~m}$ of gentians were searched for Myrmica colonies. At M. alcon sites larval food plants were difficult to find in spring because of the delayed development of $G$. pneumonanthe shoots from rhizomes and the much more delicate structure of these plants compared to G. cruciata. To overcome this difficulty, gentians loaded with eggs were marked using GPS in the previous season and only those patches were investigated next year.

Nests were not fully excavated and the search limited to higher chambers, especially in seasons when there were mainly small larvae. Destruction of nests before completion of larval growth would make development impossible and such invasive activities were avoided for reasons of conservation. Moreover the main intention of the studies was to follow the growth of the Maculinea caterpillars during their stay in Myrmica colonies. Studies were performed on warm sunny days when caterpillars were usually carried by workers into the upper parts of nests. All individuals found were recorded using a digital video camera, which allowed the later measurement of length and width (diameter) by comparison with a standard frame. We did not manage to find all the larvae and after examination the nests were immediately covered.

Ants were identified in the field using a magnifying glass and a sample of about 10 workers was collected each time to check 
TABLE 2. Summary of the results for 564 M. alcon caterpillars reared in laboratory colonies of seven different Myrmica species for eight weeks after introduction (week 0), $\mathrm{N}$ - number of caterpillars alive, $\mathrm{S}$ - percent surviving, $\mathrm{W} \pm \mathrm{S} . \mathrm{D}$. - mean body weight $(\mathrm{mg})$ and standard deviation.

\begin{tabular}{|c|c|c|c|c|c|c|c|c|c|c|}
\hline \multirow{2}{*}{ Myrmica species } & \multicolumn{10}{|c|}{ Week } \\
\hline & & 0 & 1 & 2 & 3 & 4 & 5 & 6 & 7 & 8 \\
\hline \multirow{4}{*}{$\begin{array}{l}\text { M. scabrinodis } \\
\text { from } \\
\text { M. alcon habitat }\end{array}$} & $\mathrm{N}$ & 105 & 101 & 98 & 97 & 96 & 93 & 93 & 91 & 90 \\
\hline & $\mathrm{S}$ & 100 & 96 & 93 & 92 & 91 & 89 & 89 & 87 & 86 \\
\hline & $\mathrm{W} \pm$ & 1.6 & 3.2 & 3.9 & 4.2 & 4.3 & 4.5 & 4.5 & 4.5 & 4.5 \\
\hline & S.D. & 0.4 & 1.2 & 1.8 & 2.3 & 2.2 & 2.4 & 2.4 & 2.3 & 2.3 \\
\hline \multirow{4}{*}{$\begin{array}{l}\text { M. scabrinodis } \\
\text { from } \\
\text { M. rebeli habitat }\end{array}$} & $\mathrm{N}$ & 81 & 76 & 75 & 75 & 75 & 74 & 72 & 70 & 70 \\
\hline & $\mathrm{S}$ & 100 & 94 & 93 & 93 & 93 & 92 & 89 & 86 & 86 \\
\hline & $\mathrm{W} \pm$ & 1.5 & 3.4 & 4.0 & 4.4 & 4.6 & 4.7 & 4.8 & 4.8 & 4.7 \\
\hline & S.D. & 0.3 & 1.2 & 1.6 & 2.1 & 2.2 & 2.4 & 2.6 & 2.8 & 2.6 \\
\hline \multirow{4}{*}{$\begin{array}{l}\text { M. scabrinodis } \\
\text { all cultures }\end{array}$} & $\mathrm{N}$ & 186 & 177 & 173 & 172 & 171 & 167 & 165 & 161 & 160 \\
\hline & S & 100 & 95 & 93 & 93 & 92 & 90 & 89 & 87 & 86 \\
\hline & $\mathrm{W} \pm$ & 1.5 & 3.2 & 3.9 & 4.3 & 4.5 & 4.6 & 4.6 & 4.6 & 4.6 \\
\hline & S.D. & 0.4 & 1.2 & 1.7 & 2.2 & 2.2 & 2.4 & 2.5 & 2.5 & 2.4 \\
\hline \multirow{4}{*}{ M. vandeli } & $\mathrm{N}$ & 30 & 26 & 26 & 26 & 25 & 25 & 25 & 25 & 24 \\
\hline & $\mathrm{S}$ & 100 & 87 & 87 & 87 & 83 & 83 & 83 & 83 & 80 \\
\hline & $\mathrm{W} \pm$ & 1.5 & 2.8 & 3.3 & 3.4 & 3.8 & 3.9 & 4.2 & 4.4 & 4.5 \\
\hline & S.D. & 0.3 & 0.7 & 1.0 & 1.1 & 1.7 & 2.0 & 3.0 & 3.5 & 3.7 \\
\hline \multirow{4}{*}{ M. sabuleti } & $\mathrm{N}$ & 61 & 46 & 44 & 43 & 41 & 40 & 39 & 38 & 38 \\
\hline & $\mathrm{S}$ & 100 & 75 & 72 & 71 & 67 & 66 & 64 & 62 & 62 \\
\hline & $\mathrm{W} \pm$ & 1.6 & 3.3 & 4.2 & 4.7 & 4.7 & 4.8 & 4.6 & 4.8 & 4.7 \\
\hline & S.D. & 0.4 & 1.4 & 1.7 & 2.3 & 2.1 & 2.0 & 1.7 & 1.9 & 1.8 \\
\hline \multirow{4}{*}{ M. gallienii } & $\mathrm{N}$ & 120 & 103 & 100 & 100 & 97 & 95 & 94 & 89 & 85 \\
\hline & $\mathrm{S}$ & 100 & 86 & 83 & 83 & 81 & 79 & 78 & 74 & 71 \\
\hline & $\mathrm{W} \pm$ & 1.4 & 2.6 & 3.1 & 3.2 & 3.4 & 3.5 & 3.5 & 3.7 & 4.0 \\
\hline & S.D. & 0.3 & 0.8 & 1.3 & 1.6 & 1.8 & 1.8 & 1.8 & 1.9 & 1.9 \\
\hline \multirow{4}{*}{ M. rubra } & $\mathrm{N}$ & 41 & 7 & 7 & 7 & 6 & 6 & 6 & 5 & 4 \\
\hline & $\mathrm{S}$ & 100 & 17 & 17 & 17 & 15 & 15 & 15 & 12 & 10 \\
\hline & $\mathrm{W} \pm$ & 1.5 & 2.4 & 2.8 & 2.6 & 3.1 & 2.9 & 3.1 & 3.1 & 3.0 \\
\hline & S.D. & 0.3 & 0.6 & 0.7 & 0.5 & 0.5 & 0.6 & 1.0 & 0.6 & 0.5 \\
\hline \multirow{4}{*}{ M. ruginodis } & $\mathrm{N}$ & 83 & 12 & 8 & 5 & 4 & 4 & 4 & 4 & 4 \\
\hline & $\mathrm{S}$ & 100 & 15 & 10 & 6 & 5 & 5 & 5 & 5 & 5 \\
\hline & $\mathrm{W} \pm$ & 1.4 & 2.6 & 2.9 & 3.3 & 3.7 & 3.9 & 4.0 & 3.7 & 4.2 \\
\hline & S.D. & 0.3 & 1.2 & 0.7 & 1.3 & 1.6 & 1.5 & 1.8 & 1.8 & 2.1 \\
\hline \multirow{4}{*}{ M. schencki } & $\mathrm{N}$ & 43 & 2 & 2 & 2 & 2 & 2 & 2 & 2 & 2 \\
\hline & $\mathrm{S}$ & 100 & 5 & 5 & 5 & 5 & 5 & 5 & 5 & 5 \\
\hline & $\mathrm{W} \pm$ & 1.3 & 2.5 & 2.8 & 2.9 & 3.2 & 3.4 & 3.5 & 3.8 & 3.8 \\
\hline & S.D. & 0.2 & 0.4 & 1.1 & 1.3 & 1.3 & 1.7 & 1.8 & 2.2 & 1.8 \\
\hline
\end{tabular}

the accuracy of the determination using a stereoscope microscope in the laboratory.

\section{Statistical analyses}

Differences in body weights and body volumes of Maculinea individuals reared in the laboratory or recorded in the field were tested using Wilcoxon tests. For the analyses of survival of different groups of larvae in experimental colonies the method of Cox Proportional Hazards along with the Wald test was applied. However, the growth was described using simple regression. Of the alternative models fitted, the model which yielded the highest $\mathrm{r}^{2}$ value was selected in every case.
The survival analysis was performed using Statistica 6.0 software. All other statistics were carried using Statgraphics Plus 5.0 or Excel spreadsheets.

\section{RESULTS}

\section{Survival of $M$. alcon and $M$. rebeli in the laboratory}

The mean initial weight of 564 fourth instar M. alcon caterpillars (1.55 $\pm 0.34 \mathrm{mg})$ introduced into Myrmica laboratory colonies was significantly lower $(\mathrm{W}=19210$, $\mathrm{p}<0.001)$ than that of the $192 \mathrm{M}$. rebeli caterpillars $(1.86$ $\pm 0.40 \mathrm{mg}$ ). There were no significant differences in ini- 
TABLE 3. Summary of the results for 192 M. rebeli caterpillars reared in laboratory colonies of three different Myrmica species for eight weeks after introduction (week 0 ), $\mathrm{N}$ - number of caterpillars alive, $\mathrm{S}$ - percent surviving, $\mathrm{W} \pm \mathrm{S} . \mathrm{D}$. - mean body weight (mg) and standard deviation.

\begin{tabular}{|c|c|c|c|c|c|c|c|c|c|c|}
\hline \multirow{2}{*}{ Myrmica species } & \multicolumn{10}{|c|}{ Week } \\
\hline & & 0 & 1 & 2 & 3 & 4 & 5 & 6 & 7 & 8 \\
\hline \multirow{4}{*}{$\begin{array}{l}\text { M. scabrinodis } \\
\text { from } \\
\text { M. rebeli habitat }\end{array}$} & $\mathrm{N}$ & 66 & 61 & 58 & 57 & 57 & 57 & 56 & 55 & 54 \\
\hline & $\mathrm{S}$ & 100 & 92 & 88 & 86 & 86 & 86 & 85 & 83 & 82 \\
\hline & $\mathrm{W} \pm$ & 1.9 & 6.0 & 9.1 & 11.7 & 14.9 & 18.1 & 21.0 & 24.7 & 27.2 \\
\hline & S.D. & 0.4 & 2.2 & 4.6 & 6.6 & 9.5 & 12.7 & 15.5 & 18.5 & 20.7 \\
\hline \multirow{4}{*}{$\begin{array}{l}\text { M. scabrinodis } \\
\text { from } \\
\text { M. alcon habitat }\end{array}$} & $\mathrm{N}$ & 42 & 33 & 33 & 33 & 33 & 33 & 33 & 33 & 33 \\
\hline & $\mathrm{S}$ & 100 & 79 & 79 & 79 & 79 & 79 & 79 & 79 & 79 \\
\hline & $\mathrm{W} \pm$ & 1.7 & 6.3 & 8.4 & 10.6 & 12.9 & 15.7 & 17.3 & 19.5 & 21.0 \\
\hline & S.D. & 0.4 & 3.1 & 5.4 & 7.2 & 9.8 & 13.7 & 16.3 & 19.8 & 22.5 \\
\hline \multirow{4}{*}{$\begin{array}{l}\text { M. scabrinodis } \\
\text { all cultures }\end{array}$} & $\mathrm{N}$ & 108 & 94 & 91 & 90 & 90 & 90 & 89 & 88 & 87 \\
\hline & $\mathrm{S}$ & 100 & 87 & 84 & 83 & 83 & 83 & 82 & 81 & 81 \\
\hline & $\mathrm{W} \pm$ & 1.8 & 6.1 & 8.7 & 11.1 & 13.9 & 16.8 & 18.9 & 21.5 & 23.5 \\
\hline & S.D. & 0.4 & 2.5 & 4.9 & 6.8 & 9.6 & 13.1 & 15.8 & 18.9 & 21.4 \\
\hline \multirow{4}{*}{ M. sabuleti } & $\mathrm{N}$ & 50 & 47 & 45 & 45 & 45 & 45 & 45 & 43 & 41 \\
\hline & $\mathrm{S}$ & 100 & 94 & 90 & 90 & 90 & 90 & 90 & 86 & 82 \\
\hline & $\mathrm{W} \pm$ & 1.9 & 6.5 & 8.9 & 10.9 & 13.4 & 16.1 & 18.3 & 19.4 & 20.5 \\
\hline & S.D. & 0.4 & 2.4 & 4.3 & 7.0 & 10.2 & 14.1 & 17.3 & 20.1 & 21.9 \\
\hline \multirow{4}{*}{ M. schencki } & $\mathrm{N}$ & 34 & 3 & 1 & 1 & 0 & & & & \\
\hline & $\mathrm{S}$ & 100 & 9 & 3 & 3 & 0 & & & & \\
\hline & $\mathrm{W} \pm$ & 1.5 & 6.3 & 10.5 & 7.0 & & & & & \\
\hline & S.D. & 0.5 & 3.7 & & & & & & & \\
\hline
\end{tabular}

tial body weights among caterpillars, whether M. alcon or $M$. rebeli, tested with different Myrmica species.

$M$. alcon caterpillars survived best in colonies of $M$. scabrinodis. After one week $95 \%$ of the individuals were still alive and after eight weeks dropped to $86 \%$ (Table 2). Comparison of mortality of M. alcon in M. scabrinodis colonies originating from different habitats did not reveal significant differences (Wald $=0.017, \mathrm{p}=0.90$ ). Hence, in subsequent analyses characteristics of all caterpillars reared by $M$. scabrinodis were pooled.

Survival of $M$. alcon caterpillars in M. vandeli $(80 \%$ after eight weeks), M. gallienii (69\%) and M. sabuleti colonies (62\%) was lower than in M. scabrinodis colonies, but there were significant differences only between survival in M. scabrinodis and M. sabuleti (Wald $=15.8, \mathrm{p}<0.0001)$ and M. scabrinodis and M. gallienii colonies (Wald $=9.68, \mathrm{p}<0.01)$. M. rubra, M. ruginodis and $M$. schencki were considerably worse hosts compared to all other ant species $(\mathrm{p}<0.001)$. The first and eighth week were survived by, respectively 17 and $10 \%, 15$ and $5 \%$ and 5 and $5 \%$ of all introduced caterpillars.

As far as $M$. rebeli is concerned the highest mortality was recorded for caterpillars introduced into $M$. schencki colonies. Only 9\% were alive after 7 days and none survived until the fourth week. Survival in colonies of $M$. sabuleti and M. scabrinodis was similar i.e. 94 and $82 \%$ after one week and 87 and $82 \%$ after eight weeks, respectively (Wald $=0.075, \mathrm{p}=0.78$ ). As with $M$. alcon, a comparison of the number of survivors in M. scabrinodis cultures from different habitats did not reveal significant differences (Wald $=0.213, p=0.65$ ).

A summary of the results for survival and changes in body weight of $M$. alcon caterpillars reared for eight weeks are given in Table 2 and for $M$. rebeli in Table 3.

Most of the Myrmica and/or Maculinea stock did not survive the winter i.e. a period of chilling lasting for about four months which coincided with high ant mortality. Thirteen individuals of $M$. rebeli (6 with $M$. scabrinodis and 7 with $M$. sabuleti) and only 8 of M. alcon (5 with $M$. scabrinodis, one each with $M$. vandeli, $M$. sabuleti and M gallienii) were reared to adulthood.

\section{Growth of $M$. alcon in the laboratory}

M. alcon caterpillars grew slightly during the first three weeks after introduction into ant cultures, achieving $4.4 \pm$ $2.3 \mathrm{mg}$. Then their growth stopped and the average body weight remained stable (Fig. 1). In the eighth week caterpillars weighed $4.6 \pm 2.4 \mathrm{mg}$ and the distribution was right-skewed (Fig. 2). Regression analysis fitted the reciprocal-X model to describe the relationship between mean weight $(\mathrm{y})$ and time $(\mathrm{x})$ over the eight weeks $(\mathrm{y}=$ $\left.5.14-3.57 / \mathrm{x}, \mathrm{r}^{2}=0.990, \mathrm{~F}_{1,7}=721.38, \mathrm{p}<0.001\right)$.

Thirty one $M$. alcon larvae were kept at $20^{\circ} \mathrm{C}$ for 20 weeks in colonies. After that time their mean body weight $(6.4 \pm 3.3 \mathrm{mg})$ did not differ significantly from that at eight weeks $(6.8 \pm 4.0 \mathrm{mg})$. Then they were kept at low temperature with all the other caterpillars.

Eight caterpillars of $M$. alcon, which successfully overwintered and were reared to adult stage, pupated at $82.9 \pm$ 


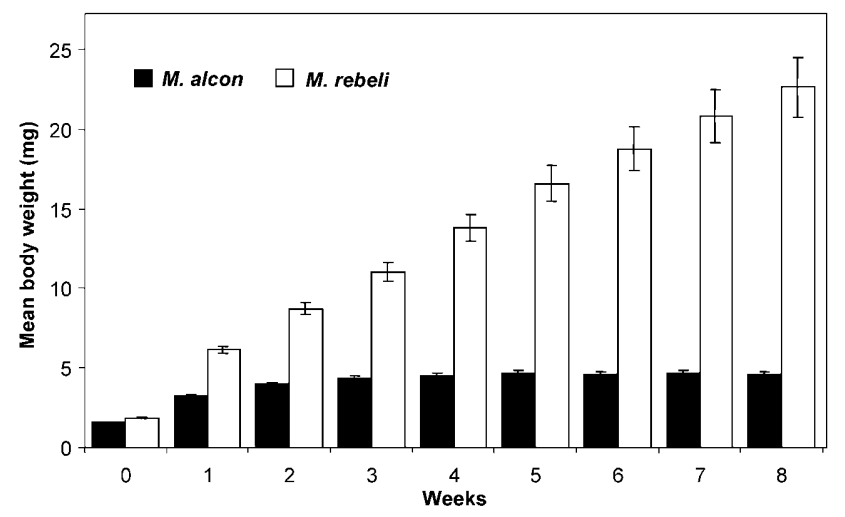

Fig. 1. Trends in the mean body weights of $M$. alcon $(\mathrm{N}=$ 236) and $M$. rebeli caterpillars $(\mathrm{N}=137)$ reared in laboratory colonies of Myrmica for 8 weeks (week 0 - introduction into a nest). The error bars represent $\pm 1 \mathrm{SE}$ of the mean. All differences between the species are significant (Mann Whitney Test, $\mathrm{p}<0.001)$.

$11.3 \mathrm{mg}$ (Table 4). Before winter they attained about $6 \%$ of the pupal biomass and lost $29 \%$ of it during the period of chilling. When the temperature increased they did not start to grow immediately but after about four weeks (Fig. 3 ) and finally pupated $68.3 \pm 13.4$ days after the end of overwintering. Duration of the pupal stage was $20.1 \pm 2.0$ days.

\section{Growth of $M$. rebeli in the laboratory}

The mean weights of fourth instar $M$. rebeli caterpillars were significantly higher than that of $M$. alcon over the whole period ( 8 weeks) of rearing at a constant temperature of $20^{\circ} \mathrm{C}$ (Fig. 1). However, infraspecific differences among larvae reared with different ant species were not significant and the comparison was of all survivors.

Average body weight of $M$. rebeli caterpillars increased significantly up to $22.6 \pm 21.4 \mathrm{mg}$ in the eighth week. The relationship between weight $(\mathrm{y})$ and time $(\mathrm{x})$ over the 8 weeks can be fitted by the square root-X model $(\mathrm{y}=$ $\left.10.40 * \sqrt{ }(\mathrm{x})-8.93, \mathrm{r}^{2}=0.996, \mathrm{~F}_{1,7}=1693.78, \mathrm{p}<0.001\right)$.

However the growth of individuals differed and generally it was possible to distinguish two groups from the third week (Fig. 4). About $41 \%$ of the 137 caterpillars grew fast. The frequency distribution of larval weights in the eighth week is presented in Fig. 2. Clear differences in weight and regular measurements at weekly intervals enabled us to follow the trajectories of every individual in this group. Regression analysis reveal a linear relationship between weight (y) of "fast" developers and time (x) over the period weeks $3-8\left(\mathrm{y}=5.42 * \mathrm{x}-3.89, \mathrm{r}^{2}=0.997\right.$, $\left.\mathrm{F}_{1,5}=1993.36, \mathrm{p}<0.001\right)$. After 56 days their mean body weight was: $44.5 \pm 18.5 \mathrm{mg}$. The remaining caterpillars
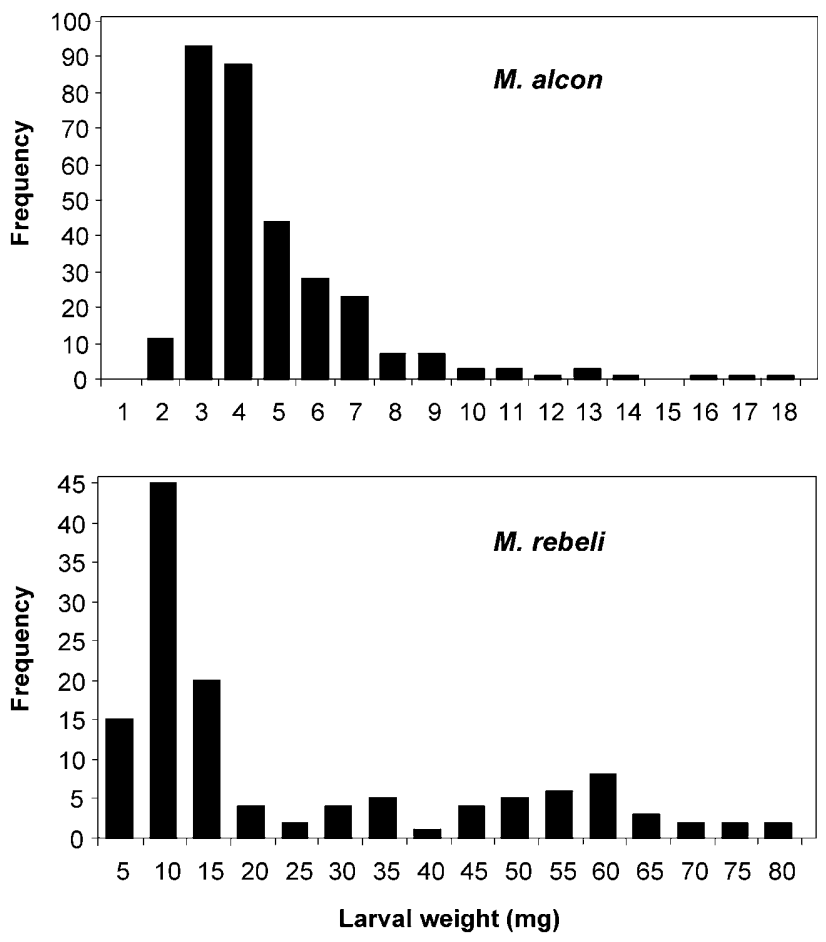

Fig. 2. Frequency distributions of the body weights of $\mathrm{Macu}$ linea alcon and M. rebeli caterpillars reared for 8 weeks in laboratory colonies of Myrmica ants.

grew only until the third week and after 56 days had achieved an average weight of $8.2 \pm 3.3 \mathrm{mg}$. Nevertheless they were twice as heavy as M. alcon caterpillars after the same period. A double reciprocal regression model describes the average growth in weight of the "slow" developers $\left(\mathrm{y}=1 /\left(0.088+0.221 / \mathrm{x}, \mathrm{r}^{2}=0.995, \mathrm{~F}_{1,5}=\right.\right.$ 1018.15, $\mathrm{p}<0.001)$.

Twenty seven $M$. rebeli caterpillars were kept for 30 weeks at a constant temperature of $20^{\circ} \mathrm{C}$. It was possible to follow the growth trajectories of individuals only after the third week when considerable variation in growth was detected (Fig. 5). Only one caterpillar had pupated after 160 days (at $92 \mathrm{mg}$ ) and a female emerged 20 days later. Body weights of 12 caterpillars increased over the period 12-21 weeks but then remained stable or started to decrease slightly and five of them died. As far as small caterpillars are concerned, six started to grow after a period of quiescence (12 to 18 weeks). Body weights of the other caterpillars remained stable and five of them died after 22-27 weeks. After 30 weeks all survivors were kept at a lower temperature but died within the next 20 weeks.

All other caterpillars after the end of the eighth week were exposed to a period of low temperature (3-4

TABLE 4. Summary of the results for 8 individuals of M. alcon and 13 of M. rebeli reared successfully to adulthood.

\begin{tabular}{|c|c|c|c|c|c|c|c|c|c|c|}
\hline & \multicolumn{2}{|c|}{$\begin{array}{l}\text { Pre-winter body } \\
\text { weight (mg) }\end{array}$} & \multicolumn{2}{|c|}{$\begin{array}{l}\text { Post-winter body } \\
\text { weight (mg) }\end{array}$} & \multicolumn{2}{|c|}{$\begin{array}{l}\text { Duration of post-winter phase } \\
\text { prior to pupation (days) }\end{array}$} & \multicolumn{2}{|c|}{$\begin{array}{l}\text { Pupal weight } \\
\text { (mg) }\end{array}$} & \multicolumn{2}{|c|}{$\begin{array}{l}\text { Duration of pupal } \\
\text { stage (days) }\end{array}$} \\
\hline & Mean & S.D. & Mean & S.D. & Mean & S.D. & Mean & S.D. & Mean & S.D. \\
\hline M. alcon & 5.1 & 1.7 & 3.6 & 1.3 & 68.3 & 13.4 & 82.9 & 11.3 & 20.1 & 2.0 \\
\hline M. rebeli & 58.3 & 16.6 & 49.1 & 15.5 & 38.6 & 4.7 & 104.0 & 19.8 & 20.1 & 2.6 \\
\hline
\end{tabular}




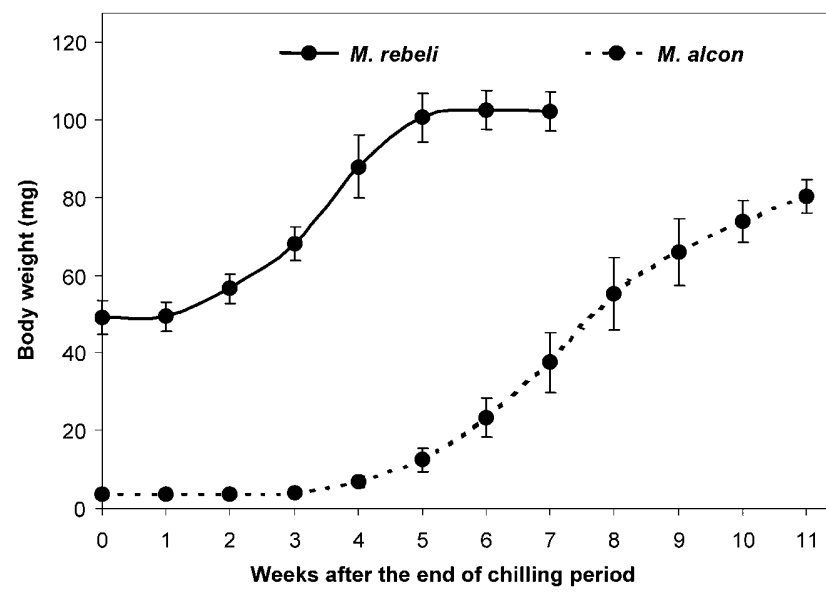

Fig. 3. Trends in the body weight (mean and S.E.) of the Maculinea alcon $(\mathrm{N}=8)$ and $M$. rebeli $(\mathrm{N}=13)$ individuals that were successfully reared throughout the post-winter phase in the laboratory. M. alcon caterpillars pupated in weeks $6-13$ and those of M. rebeli in weeks 5-7 after the end of chilling. Adults emerged in weeks $10-16$ and $8-10$, respectively.

months) and then returned to $20^{\circ} \mathrm{C}$. As for $M$. alcon most died because the ants died. However, 13 caterpillars of $M$. rebeli successfully completed development. The mean weight of pupae was $104.0 \pm 19.8 \mathrm{mg}$. They were larger than those of $M$. alcon but not significantly so $(\mathrm{W}=21.0$, $\mathrm{p}<0.05)$. Caterpillars attained about $56 \%$ of their final weight in the pre-winter phase and then lost $16 \%$ of it during the period of chilling. Caterpillars of $M$. alcon and $M$. rebeli, which successfully completed development, attained respectively about $6 \%$ and $57 \%$ of pupal weight before winter. Weight loss during the period of chilling was about $16 \%$. In contrast to $M$. alcon, M. rebeli caterpillars needed only about one week to resume growth, when the temperature was raised (Fig. 3) and pupation occurred after $38.6 \pm 4.7$ days from the end of the overwintering period. Adults emerged from pupae after $20.1 \pm$ 2.6 days, i.e., the duration of this stage was exactly the same in both species (Table 4).

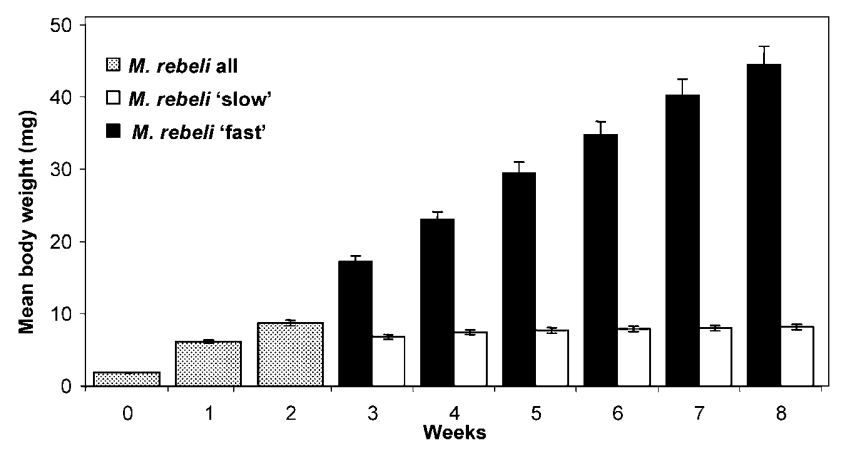

Fig. 4. Trends in the mean body weights of 137 M. rebeli caterpillars reared in laboratory colonies of Myrmica for eight weeks (week 0 - introduction to a nest). From the third week it is possible to distinguish two groups: "fast" developers, which showed a linear increase in body weight and "slow" developers, which entered a quiescent period. The error bars represent \pm 1 $\mathrm{SE}$ of the mean.

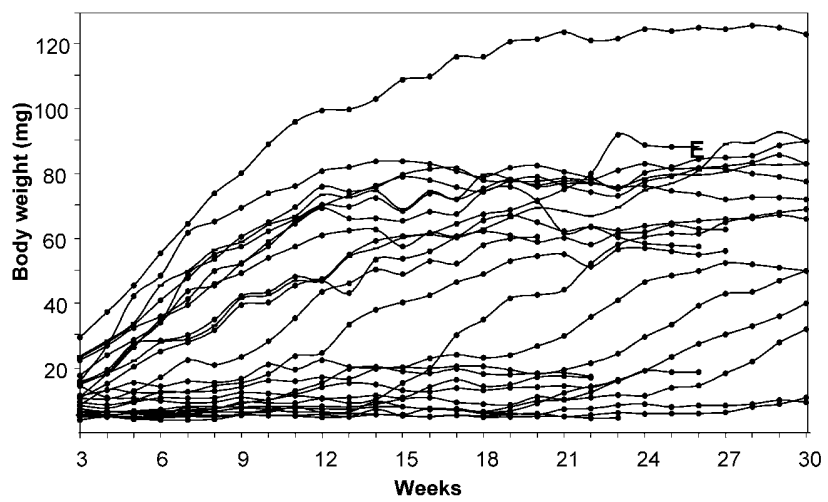

Fig. 5. Changes in body weight of $27 \mathrm{M}$. rebeli caterpillars reared for 30 weeks in six laboratory Myrmica nests at a constant temperature of $20^{\circ} \mathrm{C}$. It was possible to follow the growth trajectory of individuals only after the third week. One adult emerged (E) and 11 caterpillars died in weeks 21-27 (earlier end of a line).

There is a clear relationship between the simultaneous measurements of size and weight of caterpillars of $M$. alcon and $M$. rebeli (Fig. 6). As expected, it is described by a linear regression model $\left(\mathrm{y}=0.88 \mathrm{x}-0.65, \mathrm{r}^{2}=0.984\right.$, $\mathrm{F}=82902, \mathrm{p}<0.001)$, which was used to roughly estimate of larval body weights in the field.

\section{Growth of $M$. alcon in the field}

In late September about 60 nests of host ants near $G$. pneumonanthe plants with visible eggshells were opened. However, only ten small caterpillars were observed in the peripheral chambers of four of the M. scabrinodis nests. Their mean body volume was $3.2 \pm 1.3 \mathrm{~mm}^{3}$ (1.4-5.7 $\mathrm{mm}^{3}$ ) with a mean estimated weight of about $2.2 \mathrm{mg}$. Larvae were not looked for in the deeper parts of colonies as it would have been too destructive.

In early May, in a total of 17 nests (15 of M. scabrinodis and 2 of $M$. vandeli), 41 caterpillars were found and measured. The mean body volume was $8.6 \pm 13.3 \mathrm{~mm}^{3}$ (mean weight of about $6.9 \mathrm{mg}$ ), but the distribution of the body volumes was bimodal. Most caterpillars (35) were

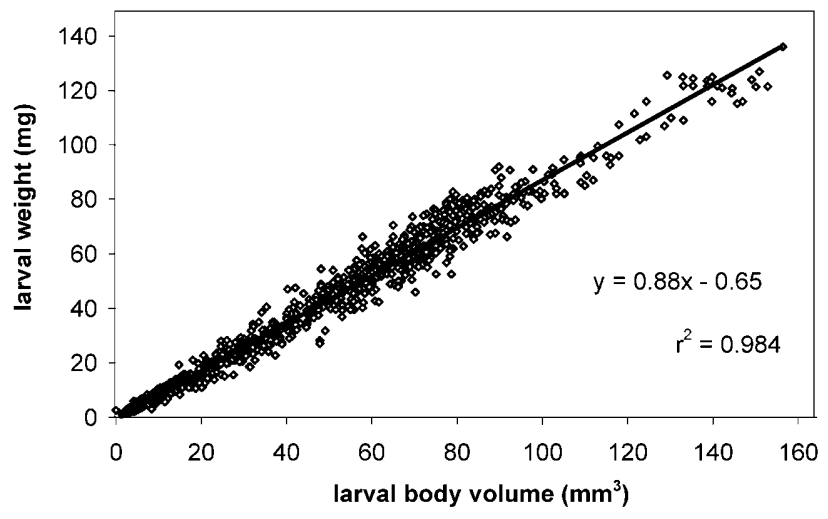

Fig. 6. The relationship between the larval weight and body volume of $M$. alcon and M. rebeli caterpillars (1384 measurements) reared in the laboratory. Equation of the linear regression can be used to roughly estimate the mean weight of larvae found in the field. 


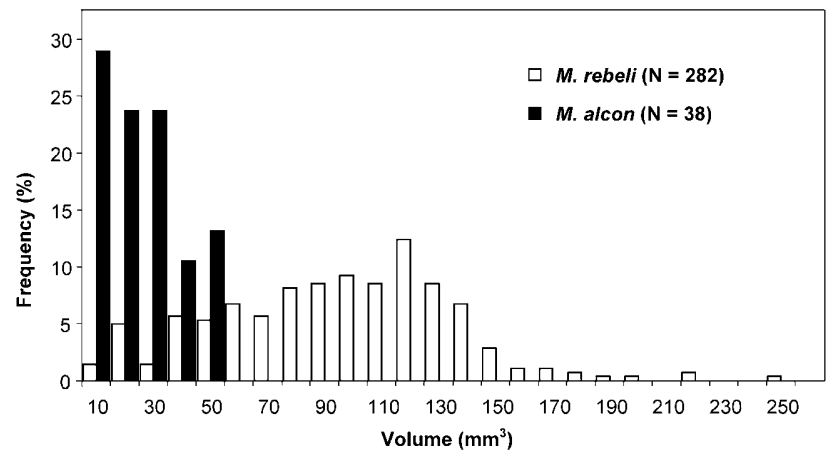

Fig. 7. Frequency distributions of the volumes of $M$. alcon and $M$. rebeli caterpillars measured in the field in late May ( $M$. rebeli site) and early June (M. alcon site).

small $\left(2.0-6.2 \mathrm{~mm}^{3}\right)$, with a mean volume of $3.9 \pm 0.9$ $\mathrm{mm}^{3}$ (estimated mean weight $2.7 \mathrm{mg}$ ), and the remainders were large, $36.0 \pm 18.7 \mathrm{~mm}^{3}\left(16.2-65.4 \mathrm{~mm}^{3}\right)$. The large caterpillars were found only in nests with very few workers. The mean volume of larvae was higher than the previous autumn $(\mathrm{W}=95.5, \mathrm{p}<0.05)$, but for particular larvae (35 individuals) the difference was insignificant ( $\mathrm{p}$ $>0.05)$.

About one month later, in early June, a total of $38 \mathrm{M}$. alcon caterpillars in 13 Myrmica nests (9 of $M$. scabrinodis, 2 of $M$. vandeli and 2 mixed colonies of both species) were measured (Fig. 7). Their mean body volume was $20.4 \pm 11.9 \mathrm{~mm}^{3}\left(4.5-43.8 \mathrm{~mm}^{3}\right)$, twice that recorded one month previously $(\mathrm{W}=1373.5, \mathrm{p}<0.001)$. The mean body weight at that time was estimated at about $17 \mathrm{mg}$.

In late June a total of 28 individuals (22 larvae and 6 pupae) were found in 12 Myrmica colonies (7 of M. scabrinodis and 5 of $M$. vandeli). Volumes were variable $\left(25.1-219.7 \mathrm{~mm}^{3}\right)$ with a mean of $123.8 \pm 51.5 \mathrm{~mm}^{3}$ and a mean estimated weight of $108 \mathrm{mg}$, i.e., six times greater than that recorded one month previously $(\mathrm{W}=12.0, \mathrm{p}<$ 0.001).

\section{Growth of $M$. rebeli in the field}

In late September caterpillars were very difficult to find without destroying nests and only 16 caterpillars from 4 nests ( 2 of $M$. sabuleti and 2 of $M$. scabrinodis) were measured. The sizes were variable (19.0-99.4 $\left.\mathrm{mm}^{3}\right)$ with a mean body volume of $53.7 \pm 22.8 \mathrm{~mm}^{3}$ (mean body weight of $47 \mathrm{mg}$ ), which was significantly greater than that of M. alcon $(\mathrm{W}=144.0, \mathrm{p}<0.001)$.

In late April the following year 146 caterpillars were found in 29 nests (19 of M. sabuleti and 10 of M. scabrinodis). Their mean body volume was $62.6 \pm 19.6 \mathrm{~mm}^{3}$ $\left(25.7-124.0 \mathrm{~mm}^{3}\right)$ with an estimated average weight of 54 $\mathrm{mg}$. They were bigger than the caterpillars recorded in autumn but not significantly so $(\mathrm{t}=-1.70, \mathrm{p}=0.09)$. However their mean body volume was about seven times greater than that of $M$. alcon larvae measured at the same time $(\mathrm{W}=5854.5, \mathrm{p}<0.001)$.

One month later, i.e. at the end of May, $282 \mathrm{M}$. rebeli prematures were measured (Fig. 7). They originated from 19 nests of M. sabuleti and 12 of M. scabrinodis. Consid-

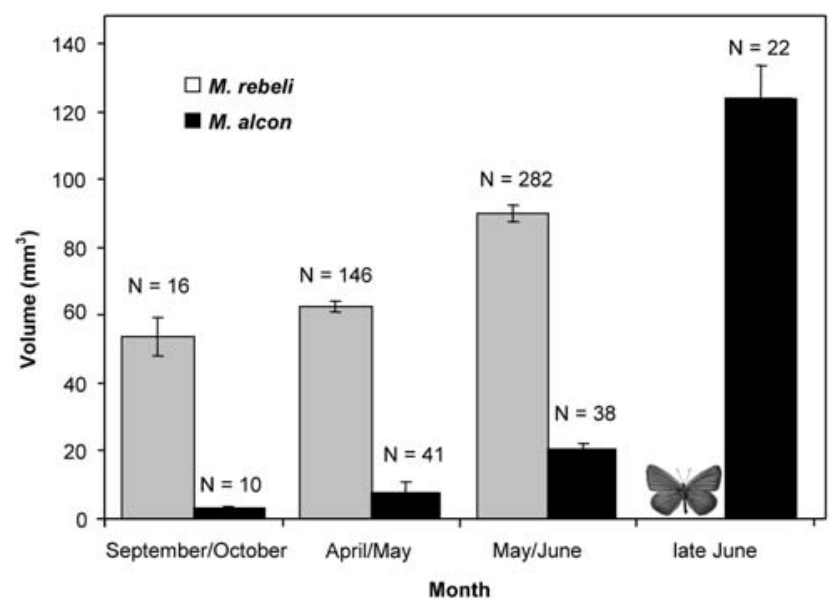

Fig. 8. Trends in the volumes of $M$. alcon and M. rebeli caterpillars/pupae from September/October to late June the following year at two field sites. The error bars represent \pm 1 SE of the mean. Peak of flight activity occurred at the end of June when only the occasional pupae can be found.

erable variation was noticed $\left(5.1-245.6 \mathrm{~mm}^{3}\right)$ and in addition to larvae three prepupae and two pupae were measured. The mean body volume of all individuals was 89.8 $\pm 39.5 \mathrm{~mm}^{3}$ with a mean estimated body weight of $78 \mathrm{mg}$, which is about $50 \%$ greater than the previous measurements at this site $(\mathrm{W}=29986, \mathrm{p}<0.001)$.

The end of June was the peak flight period of $M$. rebeli in Przemyśl in 2004. Three of about 30 nests searched contained pupae slightly variable in volume (187.0-244.7 $\mathrm{mm}^{3}$ ), with a mean value of $210.1 \pm 17.8 \mathrm{~mm}^{3}$.

The trends in the mean sizes of $M$. alcon and $M$. rebeli from September to late June the following year are illustrated in Fig. 8.

\section{DISCUSSION}

\section{Survival in the laboratory nests}

The laboratory experiments with $M$. rebeli generally confirmed field observations. Caterpillars survived well in nests of $M$. sabuleti and M. scabrinodis but quickly died in $M$. schencki colonies (Table 3). However, in the field a higher proportion of $M$. sabuleti nests was infested than of M. scabrinodis (Sielezniew et al., 2003; Sielezniew \& Stankiewicz, unpubl.). Interestingly the proportion of infested M. scabrinodis nests (about one third of all colonies found near gentians) is similar throughout Poland at $M$. alcon and $M$. rebeli sites (Sielezniew \& Stankiewicz, unpubl.). $M$. sabuleti inhabits warmer patches of turf with shorter and sparser vegetation, where it might be easier for foraging ants to find caterpillars that have dropped from plants. Other possible explanations include differences in the population structure and behaviour of workers. In spring the large polygynous nests of $M$. rubra tend to divide into smaller colonies (Czechowski, 1984). The frequent occurrence of $M$. scabrinodis colonies close to each other might also suggest colony fission in this species, but detailed studies are needed to test this hypothesis. 
Finally it is not possible to exclude that the compounds synthesized by $M$. rebeli caterpillars during their integration into a colony best mimic the odour of $M$. sabuleti. Different Myrmica species can be successfully parasitised if they are chemically similar to M. sabuleti, and some other unknown conditions are met, e.g. a favourable colony structure. Comparison of our data with ongoing extensive studies of the chemical profiles of Maculinea butterflies and Myrmica ants (Everett et al., 2005) will give new insights into the host ant specificity of $M$. rebeli. However, both field and laboratory studies indicate it is rather unlikely that $M$. rebeli caterpillars from Polish sites can be reared successfully by M. schencki, unlike some Austrian populations, which seem to show multi-host mimicry (Schlick-Steiner et al., 2004).

As far as $M$. alcon is concerned seven different $M y r-$ mica species, including five that originated from butterfly habitats, were tested. Of the "native" ants, $M$. scabrinodis, $M$. vandeli and $M$. gallienii proved to be suitable hosts for eight weeks, but the mortality rate was very high in colonies of $M$. rubra and $M$. ruginodis (Table 2). This is consistent with field data, except for $M$. gallienii, which is not recorded as a suitable host, i.e. enabling complete development. In autumn or early spring a few small caterpillars were observed in wild $M$. gallienii nests (Sielezniew \& Stankiewicz, unpubl.).

It is commonly known that Maculinea butterflies are less host specific in artificial conditions (Elmes et al., 2004). Therefore, although $M$. alcon caterpillars might be initially well integrated into $M$. gallienii colonies, it is likely they are unable to integrate fully, i.e. to achieve a high hierarchical status. Elmes et al. (2004) found that host specificity in $M$. rebeli, in stressful conditions, e.g. starvation, is more clear cut. In preliminary behavioural experiments, $M$. alcon caterpillars removed from walnut shelters were retrieved much slower by workers in $M$. gallienii than in $M$. scabrinodis laboratory colonies (Stankiewicz, unpubl.). Relatively large $M$. gallienii colonies nesting mainly in tussocks of grass or sedges in fen habitats very likely suffer a food shortage in spring when surrounding areas are often flooded. Moreover weakly integrated caterpillars are more prone to diseases, e.g. fungal infections.

The greater availability of $M$. alcon enabled us to include $M$. sabuleti and M. schencki in our experiments, ant species native to xerothermic habitats (e.g. M. rebeli ones), which are encountered only exceptionally at $M$. alcon sites. Few caterpillars introduced into M. schencki colonies survived, as is also the case for M. rebeli in colonies of this species. However M. sabuleti was a relatively good host for $M$. alcon, although survival was significantly lower than when hosted by $M$. scabrinodis. On the other hand mortality of $M$. alcon larvae hosted by $M$. sabuleti was similar to that recorded in M. vandeli colonies. $M$. vandeli and $M$. scabrinodis are about equally suitable as hosts in the field (Sielezniew \& Stankiewicz, 2004b).

Because of the shortage of $M$. rebeli stock all possible combinations were not tested, e.g. larvae reared with $M$. vandeli. Nevertheless our data indicate close similarities in the host ant specificity of Polish populations of $M$. alcon and $M$. rebeli. Therefore, host ant specificity cannot be used as an argument for separating these questioned species as in the past (Elmes et al., 1994). However, both groups of populations are distinct from $M$. alcon populations hosted by M. rubra and M. ruginodis (Elmes et al., 1994; Als et al., 2002) as well as from M. schencki dependent $M$. rebeli populations (Thomas et al., 1989; Stankiewicz et al., 2005b).

\section{Growth of caterpillars}

Growth in the pre-winter phase is the most important, visible and measurable characteristic distinguishing $M$. alcon and $M$. rebeli. If, in the field, differences can be attributed to different climatic conditions in the habitats of the species, laboratory observations strongly reject this hypothesis.

We tried to collect both $M$. alcon and $M$. rebeli almost simultaneously. Because of the difference in their flight periods we tried to collect the last available $M$. rebeli and the first available $M$. alcon larvae. However, we could not avoid a time-lag and therefore we can not exclude that the larvae of both taxa experienced different abiotic conditions in the field during the phytophagous phase of their development. Whether photoperiod and temperature experienced by larvae during the first three instars, by eggs or even by ovipositing females, influence their growth and diapause remains an open question, which can only be answered by rearing these species through their entire life cycle in the laboratory.

The mean pupal weight of the few individuals that completed their development made it possible to estimate the proportion of biomass achieved in the pre-winter phase. After 8 weeks $M$. alcon larvae had gained less than 5\% of their final weight, which is very similar to that recorded for individuals from a Spanish population with the same host ant specificity. However M. alcon caterpillars from the Netherlands and Denmark reared by $M$. ruginodis stopped growing at about one fourth of the pupal weight (Schönrogge et al., 2000).

In our experiments the mean weight of $M$. rebeli caterpillars increased in the pre-winter phase to up to $22 \%$ of their final biomass. Fast developers and slow developers achieved 44 and $8 \%$, respectively. This is consistent with the results of Elmes et al. (1991b) and Thomas et al. (1998) who studied M. rebeli from populations associated mainly with $M$. schencki.

Differences in the growth of caterpillars of $M$. alcon and $M$. rebeli in Poland reflect differences in the phenology of their larval food plants. G. cruciata shoots are available for on average about one month earlier than those of $G$. pneumonanthe, which grow in wetter and cooler habitats. Therefore the first period of rapid growth of $M$. rebeli caterpillars in late summer/early autumn is an adaptation that enables adults to synchronize their emergence with the development of the larval host plant. However, M. alcon caterpillars mainly increase in body biomass in spring, i.e. in June, in the field (Fig. 8). 
The bimodal distribution in the body weight of $M$. rebeli at the end of the pre-winter growth phase (Fig. 2) indicates a growth polymorphism, a phenomenon observed in M. rebeli and M. alcon in Western Europe. The bigger larvae pupate in one year while the smaller ones complete development in two years (Elmes et al., 1991b; Schönrogge et al., 2000). However, our laboratory observations on $M$. rebeli are not consistent with our field records where cases of growth polymorphism were much rarer than expected from the laboratory study. This is puzzling. The possibility that our non destructive technique of nest searching simply resulted in an underestimate of the number of slow developers, which may have been present in the deepest chambers, cannot be excluded. Another explanation is that a biennial life cycle is not an obligatory feature of some individuals but an adaptation induced by special conditions. In M. alcon, it is impossible to distinguish classes of caterpillars after 8 weeks. Differentiation of larval sizes in the field seems to be more the result of starvation in colonies with very few workers (see also Sielezniew \& Stankiewicz, 2004b), but the sampling method may have missed the slow developers.

The inhibition of the growth of $M$. alcon caterpillars observed in the third week after introduction persists if the period for which they are exposed to high temperature is prolonged. In M. rebeli the lack of a period of low temperature also prevents the development of almost all larvae. Of 24 larvae only one pupated after 24 weeks, others showed asynchronized growth, which sooner or later stopped (Fig. 5). Some larvae started to grow after weeks of quiescence but were unable to pupate. Only a 3-month period of cooling triggered the resumption of development, which indicates an obligatory diapause. There are records of caterpillars growing fast, and pupating within a few weeks of adoption (Tartally, 2004). To check if this occurs in Polish populations, they need to be reared under different conditions i.e. higher temperatures and an abundance of ant larvae.

Differences in diapause and growth of the caterpillars of these taxa are likely to be a mechanism for synchronizing their flight periods with the availability of host plants. This is very important because of the short life expectancy of adult butterflies (see Meyer-Hozak, 2000). This may have consequences for $M$. alcon and $M$. rebeli evolution. Steiner et al. (2006) suggest that their present questionable taxonomic status results from incomplete allopatric speciation, or ongoing ecological speciation. Both scenarios are plausible and not mutually exclusive over the whole species range. Moreover, similar ecological features, such as host ant specificity, could evolve simultaneously in allopatry. As far as we know, M. alcon and $M$. rebeli do not occur sympatrically anywhere, although their most typical larval food plants occasionally do in particular biotope complexes (Sielezniew \& Stankiewicz, 2004a). It would be interesting to find and investigate populations of both taxa present in close proximity. Differences in the flight periods of $M$. alcon and $M$. rebeli would reduce gene flow significantly, but would not in reproductive isolation in the absence of pre- or post-mating mechanisms. Nowadays the probability of finding a fine mosaic of dry and wet gentian meadows in the western and central European landscape is rather low. Therefore, ecological studies should be continued further east, in the hypothetical region of origin of Maculinea butterflies (Fiedler, 1998). In the absence of geographical barriers the existence of polymorphic populations of butterflies of the $M$. alcon group, or biotypes adapted to particular Gentianaceae plants and/or Myrmica ants, are expected. The latter feature would suggest ongoing sympatric speciation. Examples of host races in some phytophagous insects support such a theoretical possibility (Berlocher \& Feder, 2002; Drès \& Mallet, 2002). Assuming a continuation in the present rapid increase in knowledge of Maculinea butterflies, then in the near future a comparison of the results of genetic, biochemical and ecological studies is likely to provide answers about the phylogeography of $M$. alcon and M. rebeli.

\section{CONCLUSIONS}

Differences in the phenology of M. alcon and M. rebeli result from differences in the pattern of growth of the caterpillars in Myrmica nests. Our laboratory studies indicate that these differences are independent of environmental factors, which suggests a genetic basis for this phenomenon. Therefore, even if $M$. alcon and $M$. rebeli are finally judged to be only ecotypes of $M$. alcon, as some authors have already suggested (Als et al., 2004, Bereczki et al., 2005), they are in some important features quite distinct. This knowledge is important for conservation, especially future reintroduction programmes, i.e. individuals from one type of habitat or even region might not be able to adjust to another. Populations of the $M$. alcon species group show a complicated multidimensional pattern of physiological and ecological diversity associated with both larval food plants and host ants, and in the absence of detailed studies every population should be considered as a potentially distinct "conservational unit".

ACKNOWLEDGEMENTS. We are very grateful to $\mathrm{M}$. Barański, M. Niedzielska and E. Sierzan for help with laboratory experiments. A. Górnicki and M. Barański helped us in the field. We also wish to thank J. Wardlaw who taught us some of the rearing techniques and kindly provided us with Fluon. The valuable comments of three anonymous referees contributed to the improvement of the manuscript. This work was supported by KBN - The State Committee for Scientific Research (grant no. 3 P04G 026 24).

\section{REFERENCES}

Akino T., Knapp J.J., Thomas J.A. \& Elmes G.W. 1999: Chemical mimicry and host specificity in the butterfly Maculinea rebeli, a social parasite of Myrmica ant colonies. Proc. R. Soc. Lond. (B) 266: 1419-1426.

Als T.D., Nash D.R. \& Boomsma J.J. 2002: Geographical variation in host-ant specificity of the parasitic butterfly Maculinea alcon in Denmark. Ecol. Entomol. 27: 403-414.

Als T.D., Vila R., Kandul N., Nash D.R., Hsu Yen, Mignault A., Boomsma J.J. \& Pierce N.E. 2004: The evolution of alternative parasitic life histories in large blue butterflies. Nature 432: 386-390. 
Bereczki J., Pecsenye K., Peregovits L. \& Varga Z. 2005: Pattern of genetic differentiation in the Maculinea alcon species group (Lepidoptera, Lycaenidae) in Central Europe. J. Zool. Syst. Evol. Res. 43: 157-165.

Berlocher S.H. \& Feder J.L. 2002: Sympatric speciation in phytophagous insects: moving beyond controversy? Аnnu. Rev. Entomol. 47: 773-815.

Czechowski W. 1984: Colony fission and intraspecific contests in Myrmica laevinodis Nyl. (Hymenoptera, Formicidae). Ann. Zool. 38: 99-109.

Czechowski W., Radchenko A. \& Czechowska W. 2002: The Ants (Hymenoptera, Formicidae) of Poland. Museum and Institute of Zoology PAS, Warsaw, $200+1 \mathrm{pp}$.

Drès M. \& MALLET J. 2002: Host races in plant feeding insects and their importance in sympatric speciation. Phil. Trans. R. Soc. Lond. (B) 357: 471-492.

Elmes G.W., Thomas J.A., Hammarstedt O., Munguira M.L., Martin J. \& van der Made J.G. 1994: Differences in hostants specificity between Spanish, Dutch and Swedish populations of the endangered butterfly Maculinea alcon (Denis et Schiff.) (Lepidoptera). Memorab. Zool. 48: 55-68.

Elmes G.W., Thomas J.A., Wardlaw J.C., Hochberg M.E., Clarke R.T. \& Simcox D.J. 1998: The ecology of Myrmica ants in relation to the conservation of Maculinea butterflies. $J$. Insect Cons. 2: 67-78.

Elmes G.W., Thomas J.A. \& Wardlaw J.C. 1991a: Larvae of Maculinea rebeli, a large-blue butterfly, and their Myrmica host ants: wild adoption and behaviour in ant-nest. J. Zool. Lond. 223: 447-460.

Elmes G.W., Wardlaw J.C. \& Thomas J.A. 1991b: Larvae of Maculinea rebeli, a large-blue butterfly, and their Myrmica host ants: patterns of caterpillars growth and survival. J. Zool. Lond. 224: 79-92.

Elmes G.W., Akino T., Thomas J.A., Clarke R.T. \& Knapp J.J. 2002: Interspecific differences in cuticular hydrocarbon profiles of Myrmica ants are sufficiently consistent to explain host specificity by Maculinea (large blue) butterflies. Oecologia 130: 525-535.

Elmes G.W., Wardlaw J.C., Schönrogge K., Thomas J.A. \& CLARKE R.T. 2004: Food stress causes differential survival of socially parasitic caterpillars of Maculinea rebeli integrated in colonies of host and non-host Myrmica ant species. Entomol. Exp. Appl. 110: 53-63.

Everett S., Worgan A.D.P., Sielezniew M., Stankiewicz A., Nash D.N., Wynne I., Nowicki P., Tartally A., Peregowitz L., Tesar D., Maes D., Wynhof I., Anton C., Musche M., Bonelli S., Wardlaw J.C., Csósz S., Simcox D.J., Elmes G.W., Woyciechowski M., Varga Z., Settele J., Thomas J.A., SCHÖNROGGE K. 2005: Variation in chemical profiles of Maculinea and their Myrmica hosts across Europe. In Settele J., Kühn E. \& Thomas J.A. (eds): Studies on the Ecology and Conservation of Butterflies in Europe. Vol. 2: Species Ecology along a European Gradient: Maculinea Butterflies as a Model. Pensoft, Sofia, pp. 174-177.

FIEDLER K. 1998: Lycaenid-ant interactions of the Maculinea type: tracing their historical roots in a comparative framework. J. Insect Cons. 2: 3-14.

JUTZELER D. 1988: Fund von Maculinea rebeli (Hirschke, 1904) im Glarnerland (Lepidoptera, Lycaenidae). Mitt. Entomol. Ges. Basel 38: 124-125.

Kolev Z. 2002: The species of Maculinea van Ecke, 1915 in Bulgaria: distribution, state of knowledge and conservation status (Lycaenidae). Nota Lepid. 26: 177-190.

MeYer-HozaK C. 2000: Population biology of Maculinea rebeli (Lepidoptera: Lycaenidae) on the chalk grasslands of Eastern
Westphalia (Germany) and implications for conservation. $J$. Insect Cons. 4: 63-72.

Munguira M.L. \& Martin J. 1999: Action Plan for the Maculinea Butterflies in Europe. Nature and Environment, No. 97. Council of Europe Publishing, Strasbourg, 64 pp.

Pech P., Fric Z., KonvičKa M. \& ZrzavÝ J. 2004: Phylogeny of Maculinea blues (Lepidoptera: Lycaenidae) based on morphological and ecological characters: evolution of parasitic myrmecophily. Cladistics 20: 362-375.

Radchenko A., Elmes G.W., Czechowska W., Stankiewicz A., Czechowski W. \& Sielezniew M. 2003: First records of Myrmica vandeli Bondroit and M. tulinae Elmes Radchenko et Aktaç (Hymenoptera: Formicidae) for Poland, with a key for the scabrinodis- and sabuleti-complexes. Fragm. Faun. 46: $47-57$.

Schlick-Steiner B.C., Steiner F.M., Höttinger H., Nikiforov A., Mistrik R., Schafellner C., Baier P. \& Christian E. 2004: Multi-host mimicry via union-odour: A butterfly's chemical key to various ant forts. Naturwissenschaften 91: 209-214.

SchönRogge K., Wardlaw J.C., Thomas J.A. \& Elmes G.W. 2000: Polymorphic growth rates in myrmecophilous insects. Proc. R. Soc. London (B) 267: 1-7.

Schönrogge K., Wardlaw J.C., Peters A.J., Everett S., Thомas J.A. \& Elmes G.W. 2004: Changes in chemical signature and host specificity from larval retrieval to full social integration in the myrmecophilous butterfly. J. Chem. Ecol. 30: $91-107$.

Settele J., Kühn E. \& Thomas J.A. 2005: Studies on the Ecology and Conservation of Butterflies in Europe. Vol. 2: Species Ecology along a European Gradient: Maculinea Butterflies as a Model. Pensoft, Sofia, 289 pp.

Sielezniew M. \& Stankiewicz A. 2002: First data on host-ant specificity of parasitic butterfly Maculinea alcon (Den. \& Schiff.) (Lepidoptera: Lycaenidae) in Poland and eastern Europe. Fragm. Faun. 45: 123-130.

Sielezniew M. \& Stankiewicz A. 2004a: Gentiana cruciata as an additional host plant of Maculinea alcon on a site in Eastern Poland. Nota Lepid. 27: 91-93.

Sielezniew M. \& Stankiewicz A. 2004b: Simultaneous exploitation of Myrmica vandeli and M. scabrinodis (Hymenoptera: Formicidae) colonies by the endangered myrmecophilous butterfly Maculinea alcon (Lepidoptera: Lycaenidae). Eur. J. Entomol. 101: 693-696.

Sielezniew M., Stankiewicz A., Łuczaj Ł. \& GóRnicki A. 2003: On the distribution and the ecology of Mountain Alcon Blue, Maculinea rebeli Hirschke (Lepidoptera, Lycaenidae) in Poland. Przegl. Zool. 47: 211-220 [in Polish, English abstr.].

Stankiewicz A.M., Sielezniew M. \& Barański M. 2005a: The first record of Myrmica rugulosa Nylander, 1849 (Hymenoptera: Formicidae) as a host-ant of Maculinea rebeli Hirschke, 1904 (Lepidoptera: Lycaenidae). Pol. J. Entomol. 74: 99-103.

Stankiewicz A.M., Sielezniew M. \& Buszko J. 2005b: Maculinea alcon and M. rebeli in Poland: distribution, habitats, host ant specificity and parasitoids. In Settele J., Kühn E. \& Thomas J.A. (eds): Studies on the Ecology and Conservation of Butterflies in Europe. Vol. 2: Species Ecology along a European Gradient: Maculinea Butterflies as a Model. Pensoft, Sofia, pp. 90-93.

Stankiewicz A.M., Sielezniew M. \& Švitra G. 2005c: Myrmica schencki rears Maculinea rebeli in Lithuania: new evidence for geographical variation of host-ant specificity of an endangered butterfly. Myrmecol. Nachr. 7: 51-54.

Steiner F.M., Sielezniew M., Schlick-Steiner B.C., Höttinger H., Stankiewicz A. \& Górnicki A. 2003: Host specificity 
revisited: New data on Myrmica host ants of the lycaenid butterfly Maculinea rebeli. J. Insect Cons. 7: 1-6.

Steiner F.M., Schlick-Steiner B.C., Höttinger H., Nikiforov A., Moder K. \& Christian E. 2006: Maculinea alcon and M. rebeli (Insecta: Lepidoptera: Lycaenidae) - one or two Alcon Blues? Larval cuticular compounds and egg morphology of East Austrian populations. Ann. Naturhist. Mus. Wien. 107: 165-180.

TARTALly A. 2004: Accelerated development of Maculinea rebeli larvae under artificial conditions (Lycaenidae). Nota Lepid. 27: 303-308.

Tartally A. 2005: Myrmica salina (Hymenoptera: Formicidae) as a host of Maculinea alcon (Lepidoptera: Lycaenidae) Sociobiology 46: 39-43

Tartally A. \& Varga Z. 2005: Host-ant specificity of Maculinea species in Hungary, connections with parasitoids and host plants. In Settele J., Kühn E. \& Thomas J.A. (eds): Studies on the Ecology and Conservation of Butterflies in Europe. Vol. 2: Species Ecology along a European Gradient: Maculinea Butterflies as a Model. Pensoft, Sofia, pp. 94-98.
Thomas J.A. \& Settele J. 2004: Butterfly mimics of ants. Nature 432: 283-284.

Thomas J.A., Elmes G.W. \& Wardlaw J.C. 1998: Polymorphic growth in larvae of the butterfly Maculinea rebeli, a social parasite of Myrmica ant colonies. Proc. R. Soc. Lond. (B) 265: 1895-1901.

Thomas J.A., Elmes G.W., Wardlaw J.C. \& Woyciechowski M. 1989: Host specificity among Maculinea butterflies in Myrmica ant nests. Oecologia 79: 425-457.

Van SwaAy C.A.M. \& Warren M. 1999: Red Data Book of European Butterflies (Rhopalocera). Nature and Environment, No. 99. Council of Europe Publishing, Strasbourg, 260 $\mathrm{pp}$

WARDLAW J.C. 1991: Techniques for rearing Myrmica ants (Hym.) and Maculinea rebeli Hir. caterpillars (Lep., Lycaenidae). Entomol. Mon. Mag. 127: 233-241.

Wardlaw J.C., Elmes G.W. \& Thomas J.A. 1998: Techniques for studying Maculinea butterflies: I. Rearing Maculinea caterpillars with Myrmica ants in the laboratory. J. Insect Cons. 2: 79-84.

Received May 12, 2006; revised and accepted March 19, 2007 